\title{
Androgens and Anemia: Current Trends and Future Prospects
}

\author{
Ahmed Al-Sharefi ${ }^{\text {* }}$, Azmi Mohammed ${ }^{2}$, Altayeb Abdalaziz ${ }^{3}$ and Channa N. Jayasena ${ }^{1}$ \\ ${ }^{1}$ Section of Investigative Medicine, Imperial College London, Hammersmith Hospital, London, United Kingdom, ${ }^{2}$ The James \\ Cook University Hospital, South Tees Hospitals NHS Foundation Trust, Middlesbrough, United Kingdom, ${ }^{3}$ The Royal Victoria \\ Infirmary, Newcastle Hospitals NHS Foundation Trust, Newcastle upon Tyne, United Kingdom
}

Keywords: anemia, hypogonadism, anemia of chronic kidney disease, testosterone treatment, erythropoesis, haematocrit (HcT)

\section{INTRODUCTION}

The regulatory effects of androgens on haematopoiesis have been recognized since the early twentieth century. Castration of male rats causes anemia (1) which is reversible after treatment with androgens (2). A classical clinical study by Vahlquist provided indirect evidence that men had intrinsically higher haematocrit (Hct) levels when compared with women; it was observed that

\section{OPEN ACCESS}

Edited by:

Richard Quinton,

Newcastle University, United Kingdom

Reviewed by:

Ravikumar Balasubramanian,

Partners Healthcare, United States

Giulia Rastrelli,

University of Florence, Italy

Andrea Sansone,

Sapienza University of Rome, Italy

*Correspondence:

Ahmed Al-Sharefi

a.al-sharefi@imperial.ac.uk

Specialty section:

This article was submitted to

Reproduction,

a section of the journal

Frontiers in Endocrinology

Received: 10 April 2019

Accepted: 18 October 2019

Published: 14 November 2019

Citation:

Al-Sharefi A, Mohammed A,

Abdalaziz A and Jayasena CN (2019)

Androgens and Anemia: Current

Trends and Future Prospects.

Front. Endocrinol. 10:754

doi: 10.3389/fendo.2019.00754 pre-menopausal women did not have higher Hct levels when compared with post-menopausal women, and did have an increased Hct in response to iron supplementation (3). Anecdotal data from competitive athletes suggest that androgen misuse can improve performance, partly through increasing the $\mathrm{VO}_{2} \max$ (Hb-mediated blood oxygen carrying capacity), albeit at the expense of an increased risk of arterial and venous thrombosis (4). Equally, women suffering from hyperandrogenic endocrinopathies such as congenital adrenal hyperplasia and Cushing's syndrome, may exhibit relative erythrocytosis $(5,6)$. The above historic findings underpin the androgens on stimulating bone morrow erythropoiesis.

\section{TESTOSTERONE (T) AND OTHER ANDROGENS}

$\mathrm{T}$, the principal circulating androgen in men, is a steroid hormone biosynthesized from cholesterol with its biological action mediated through binding and activation of androgen receptors in androgenic tissues after conversion, by $5 \alpha$-reductase enzyme, to its more potent form dihydrotestosterone (DHT) (7). Since 1935, when the first T was isolated (8) different T preparations and routes were developed including several forms of the longer-acting $T$ esters such T enanthate, T cypionate, and subsequently $\mathrm{T}$ undecanoate (9-11).

By 1970, several synthetic steroidal androgens were also available comprising groups of $17 \alpha$-alkylated androgens, 1-methyl androgens, and nandrolone (12). As most of the oral 17 $\alpha$ alkylated androgens have hepatotoxic effect, they were not suitable as long term options for androgen replacement therapy (12). However, some of these androgens (such as danazol and stanozolol) along with other 1-methyl androgen (like methenolone) were used to treat aplastic anemia and anemia due to myelofibrosis (13-15).

Unlike T, nandrolone (19-nor testosterone) is metabolized by $5 \alpha$-reductase to its much weaker metabolite $5 \alpha$-dihydronandrolone (DHN), giving it a very high ratio of anabolic to androgenic activity (16). Due to this anabolic effect, it can be used in certain clinical indications such as severe burns, HIV-associated cachexia, and chronic obstructive lung diseases (17). Nevertheless, this anabolic potency unfortunately makes nandrolone and its derivatives (such as Trenbolone) an attractive substance to misuse for physique- and performance-enhancing purposes. 


\section{ANDROGENS AND ERYTHROPOIESIS}

Animal and human studies suggested a direct and indirect stimulatory effect of androgens on erythropoiesis, though the exact mechanism of such relation remains vaguely understood. Androgens administration results in an increase in the erythroid cell mass, the colony forming units for erythrocytes (CFU-E), and the production and secretion of Erythropoietin (EPO) (6) while androgen deprivation causes a reduction in red blood cell indices due to reduced proliferation of marrow erythroid precursors (18).

Androgens are converted to 17-keto-steroids capable of increasing the synthesis of mRNA in the nucleus causing differentiation of bone marrow cells from EPO-non-responsive to EPO responsive (6). Moreover, androgens enhances the glucose uptake resulting in glycolysis and gene transcription and mRNA synthesis in erythroid (19-21).

T may increase Hct by inhibiting secretion of hepcidin, the principal iron regulatory peptide, thereby leading to an increase in bioavailable iron (22) but may also enhance the incorporation of iron into the red blood cells (23) and improve red blood cells survival (24). Finally, the finding of raised insulin like growth factor 1 (IGF-1) levels in those receiving androgens suggested a potential link between androgens and an IGF-1 driven erythroid progenitor cells proliferation and differentiation $(25,26)$.

The effect of $\mathrm{T}$ on erythropoiesis is most pronounced during puberty, with prepubertal $\mathrm{Hb}$ being similar in boys and girls, but increases in boys after age 13 years in tandem with increasing $\mathrm{T}$ concentrations $(6,27)$. Boys with delayed puberty have $\mathrm{Hb}$ levels similar to those of prepubertal boys and girls, and treatment with T normalizes hemoglobin levels to those observed in the late male puberty $(28,29)$.

\section{HYPOGONADISM AND ANEMIA OF CHRONIC KIDNEY DISEASE (CKD)}

Prior to the development of EPO therapy in the late 1980s, androgens were the only option for treating CKD-related anemia in men. Patients with CKD may have impairment of bone mineral density, muscle bulk, energy levels, quality of life, and sexual function, with adverse cardiovascular outcomes, especially in those with concurrent diabetes (30); while these features are likely multi-factorial in origin, they also occur during hypogonadism. Low $\mathrm{T}$ is prevalent among CKD patients and may contribute to renal anemia $(31,32)$. Up to two thirds of men on hemodialysis (HD) have serum $\mathrm{T}$ levels in the hypogonadal range, resulting from abnormalities at all levels in the hypothalamic-pituitarytesticular axis (33-36). Unpublished data from a cohort of 113 HD \& 85 pre-dialysis (preD) stage 4 and 5 CKD patients reported a subnormal T levels were in $76 \%$ of pre-dialysis and $80 \%$ in HD males with a significant inverse correlation of $\mathrm{D} \alpha$ dose with total $\mathrm{T}(\mathrm{R}-0.253 ; p<0.01)$ and free $\mathrm{T}(-0.29 ;<0.01)(37)$.

$\mathrm{T}$ concentrations have been found to inversely correlate with all-cause and cardiovascular-related mortality, as well as with markers of inflammation in patients with dialysis dependent end stage renal disease $(32,38)$. Even in those with non-dialysis dependent kidney disease, low total $\mathrm{T}$ was associated with higher mortality (39). However, it remains unclear if $\mathrm{T}$ treatment in those with CKD-anemia and hypogonadism, could positively influence mortality in this high risk cohort.

The fact that hypogonadism is a well-established cause for anemia and reduced responsiveness to EPO in men with CKD may suggest a possible role for $\mathrm{T}$ therapy as an adjunct or an alternative to EPO in some men with CKD-related anemia (40). This is particularly relevant in some healthcare systems where CKD patients are unable to afford EPO therapy which might result in anemia requiring blood transfusion, especially while there is a lacking evidence that EPO improves morbidity or mortality in CKD (41).

The Cochrane systemic review for the use of androgen in treating anemia of CKD did not find sufficient evidence to confirm the benefit of androgen therapy in treating anemia of CKD (42). The Cochrane systemic review excluded 20 studies for either being non-randomized controlled trials, of $<6$ months duration, if treatment and control groups data were indistinct or if it was unknown if participants received any androgen therapy for the preceding 6 months. The review only included data from 8 studies with sample sizes ranging between 9 and 37 participants. Limitations of the included studies include lack of matching for hypogonadism at baseline, and the absence of titrating $\mathrm{T}$ doses to reach therapeutic levels. In a meta-analysis of 4 randomized controlled trial including men over the age of 50 years, nandrolone was non-inferior to EPO for the treatment of anemia of CKD, especially in developing countries where EPO might be unavailable (43).

It has been argued that androgen therapy may potentiate the effectiveness of EPO treatment and reduces the minimal EPO dose necessary to maintain satisfactory $\mathrm{Hb}$ level in patients undergoing HD (44). Additional benefits of $\mathrm{T}$ in patients with CKD may include improvement of sexual function (45), muscle mass, functional performance, quality of life and subsequently, could ameliorate frailty (46). However, these potential benefits require formal investigation to assess the clinical benefits vs. risk of therapy.

\section{HYPOGONADISM AND UNEXPLAINED ANEMIA IN THE ELDERLY}

Anemia in the elderly men may increase morbidity and mortality risk. In a retrospective study of men aged over 65 years admitted with acute myocardial infarction, lower Hct levels were associated with an increase in the 30-day mortality while treating the anemia improved the mortality rates (47). Similar observation of high mortality was reported in a cohort of anemia patients presenting with new onset heart failure (48).

Increasing age per se was previously thought to be a risk factor for developing anemia, since anemia prevalence dramatically rises after the age of 50 years and affects up to $20 \%$ of 85 year olds (49). Several causes for anemia in the elderly have been reported in the non-institutionalized United States population in the third National Health and Nutrition Examination Survey; nutritional factors, anemia of CKD, blood loss, bone marrow myelodysplasia were causative of anemia in around 
$2 / 3$ of the population while in the remaining $1 / 3$, anemia was unexplained $(49,50)$. Currently, the patho-physiological basis for "aging" anemia remains incompletely understood and the term "unexplained" anemia is still a common diagnosis in older men (51).

Hypogonadism and aging may both cause anemia, sarcopenia, and osteoporosis (52) with longitudinal and cross-sectional studies consistently showing a declining serum levels of $\mathrm{T}$ in aging men.

An analysis of the European male aging study (EMAS) data found that primary hypogonadism $(\mathrm{PH})$ was strongly related to aging but not obesity, while secondary hypogonadism $(\mathrm{SH})$ was linked to obesity, irrespective of age (53). In most aging men, "functional hypogonadism" is a reflection of the physiological burden of obesity, inflammation and accumulating comorbidities on the hypothalamus -pituitary-gonadal axis, however; it is unclear if this effect is adaptive (diverts resources from reproduction to survival), maladaptive (exacerbated diseaserelated frailty), or neutral. Indeed, the EMAS found that $1-2 \%$ of the general population of elderly men can show a clinical picture of $\mathrm{PH}$ or late onset hypogonadism (LoH), characterized by low $\mathrm{T}$ and raised gonadotrophins, attributed to age-related primary testicular failure $(52,54)$. Men with elevated serum follicle stimulating hormone (FSH) and normal levels of luteinizing hormone (LH) and T may have a reduced spermatogenesis with entirely normal testicular androgen production. In some men, a compensated dysregulation of gonadal function "compensated hypogonadism" is characterized by raised $\mathrm{LH}$ with normal $\mathrm{T}$, reflecting a state of age-related health deterioration with potential progression to primary hypogonadism (55).

Whereas, organic secondary hypogonadism (low-normal $\mathrm{LH}+\mathrm{FSH}$ ) is biochemically indistinguishable from non-gonadal illness effect, $\mathrm{PH}$ can be easily diagnosable even in the acute (or chronic) disease settings, subject to the potential for the LH+FSH rise being blunted with intercurrent illness and/or medication (especially opiates).

In a retrospective study of 67 hospitalized elderly men (56), $\mathrm{PH}$ was found to be a surprisingly common cause of anemia among an unselected population of older male medical inpatients, $20.6 \%(7 / 34)$ of total cases with anemia and $43 \%$ (7/16) of those with otherwise unexplained anemia. Older men with $\mathrm{PH}$ and anemia therefore constitute a homogeneous group that can be reliably diagnosed and would thus represent an excellent potential cohort for examining the effects of $T$ replacement therapy on haematopoiesis and other markers of frailty.

\section{EFFECT OF T THERAPY ON ANEMIA}

Studies have examined $\mathrm{Hb}$ changes in patients receiving $\mathrm{T}$ replacement therapy; some specifically trialing $\mathrm{T}$ therapy with the primary aim of improve anemia, with an accumulating body of evidence. In a randomized double blinded placebo-controlled study by Dhinsda et al., $\mathrm{T}$ therapy suppressed hepcidin with a marked increase in the Hb, EPO and expression of ferroportin and transferrin receptors in hypogonadal patients with type 2 diabetes (57). The National Institute of Health (NIH)-funded $\mathrm{T}$ Trials examined the effects of $\mathrm{T}$ therapy in hypogonadal men aged $>65$ years (58). Using a double-blinded, placebocontrolled design, 12 months of daily $\mathrm{T}$ gel treatment increased $\mathrm{Hb}$ levels by at least $1.0 \mathrm{~g} / \mathrm{dL}$ in $\sim 52 \%$ of more men with hypogonadism and a known cause of anemia when compared with placebo. Furthermore, in the 64 older men with unexplained anemia; $\mathrm{Hb}$ improved by at least $1.0 \mathrm{~g} / \mathrm{dL}$ in $54 \%$ of men vs. $15 \%$ in the placebo group. Nevertheless, androgen deficiency (AD) is typically overlooked in guidelines on the investigation of anemia (59).

It is important to note that most clinical guidelines recommend that Hct and prostate specific antigen (PSA) are assessed prior to initiating $\mathrm{T}$ therapy (60).

\section{FUTURE CONSIDERATIONS}

As life-expectancy increases, aging and frailty have become increasing health priorities worldwide. For instance, the number of people over 65 years of age is projected to reach $15-20 \%$ of the entire population by $2030(61,62)$. Unexplained anemia is common in older men, hypogonadism accounts for a proportion of these cases. Hypogonadism may negatively impact men's health and aggravate frailty, morbidity and mortality. Androgen therapy also has potential to treat anemia of CKD in hypogonadal men as an adjunct to EPO. Given the long-standing risks associated with $\mathrm{T}$ therapy, further studies are required to determine which men would most benefit functionally from $\mathrm{T}$ therapy without exposing them to unnecessary adverse effects or long-term complications.

\section{AUTHOR CONTRIBUTIONS}

AA-S drafted the structure of the article while AM and AA collected the relevant data as per AA-S guidance. AM and AA wrote the initial draft which was revised, edited, and expanded by AA-S. CJ supervised the manuscript's writing process and approved the final version.

\section{FUNDING}

The Section of Investigative Medicine was funded by grants from the MRC, BBSRC, and was supported by the NIHR Imperial Biomedical Research Center Funding Scheme. The following authors have grant funding as follows: CJ (NIHR PostDoctoral Fellowship; NIHR Health Technology Assessment), AA-S (The imperial college private health care fellowship). The views expressed are those of the authors and not necessarily those of the above mentioned funders, the NHS, the NIHR, or the Department of Health. 


\section{REFERENCES}

1. Steinglass P, Gordon AS, Charipper HA. Effect of castration and sex hormones on blood of the rat. Proc Soc Exp Biol Med. (1941) 48:169-77. doi: 10.3181/00379727-48-13259

2. Crafts RC. Effects of hypophysectomy, castration and testosterone propionate on hemopoiesis in the adult male rat. Endocrinology. (1946) 39:401-13. doi: 10.1210/endo-39-6-401

3. Vahlquist B. The cause of the sexual differences in erythrocyte, hemoglobin and serum iron levels in human adults. Blood. (1950) 5:874-5. doi: 10.1182/blood.V5.9.874.874

4. Hartgens F, Kuipers S. Effects of androgenic-anabolic steroids in athletes. Sports Med. (2004) 34:513-54. doi: 10.2165/00007256-200434080-00003

5. McCullagh EP, Jones R. A note on the effect of certain androgens upon red blood cell count and upon glucose tolerance. Cleve Clin Q. (1941) 8:79-84. doi: $10.3949 /$ ccjm.8.2.79

6. Shahani S, Braga-Basaria M, Maggio M, Basaria S. Androgens and erythropoiesis: past and present. J Endocrinol Invest. (2009) 32:704-16. doi: $10.1007 / \mathrm{BF} 03345745$

7. Luetjens CM, Weinbauer GF. Chapter 2: Testosterone: biosynthesis, transport, metabolism and (non-genomic) actions. In: Nieschlag E, Behre HM, Nieschlag S, editors. Testosterone: Action, Deficiency, Substitution. 4th ed. Cambridge: Cambridge University Press (2012). p. 15-32. doi: 10.1017/CBO9781139003353.003

8. Taylor WN. Anabolic Steroids and the Athlete, 2nd ed. McFarland, CA: McFarland \& company inc. (2002). p. 180.

9. Oberman J. Testosterone Dreams: Rejuvenation, Aphrodisia, Doping. Berkeley, CA; Los Angeles, CA: University of California Press (2005). p. 134.

10. Mundy AR, Fitzpatrick J, Neal DE, George NJ. The Scientific Basis of Urology. New York, NY: CRC Press (2010). p. 294.

11. Srinivas-Shankar U, Wu FCW. Drug insights: testosterone preparations Nat Clin Pract Urol. (2006) 3:653-65. doi: 10.1038/ncpuro0650

12. Handelsman DJ. Androgen physiology, pharmacology, and abuse. In: Jameson JL, De Groot LJ, de Kretser D, Giudice LC, Grossman A, Melmed S, Potts JT Jr, Weir GC, editors. Endocrinology: Adult and Pediatric, 7th ed. Elsevier (2016). p. 2368-93.e16. Available online at: https://www.sciencedirect.com/science/ article/pii/B9780323189071120013

13. Najean Y, Pecking A, Le Danvic M, The Cooperative Group for the Study of Aplastic and Refractory Anaemias Secretaries. Androgen therapy of aplastic anaemia-A prospective study of 352 cases. Scand J Haematol. (1979) 22:34356. doi: 10.1111/j.1600-0609.1979.tb00430.x

14. Shimoda K, Shide K, Kamezaki K, Okamura T, Harada N, Kinukawa N, et al. The effect of anabolic steroids on anemia in myelofibrosis with myeloid metaplasia: retrospective analysis of 39 patients in Japan. Int J Hematol. (2007) 85:338-43. doi: 10.1532/IJH97.06135

15. Jaime-Pérez JC, Colunga-Pedraza PR, Gómez-Ramírez CD, GutiérrezAguirre CH, Cantú-Rodríguez OG, Tarín-Arzaga LC, et al. Danazol as first-line therapy for aplastic anemia. Ann Hematol. (2011) 90:523-7. doi: 10.1007/s00277-011-1163-x

16. Kicman AT. Pharmacology of anabolic steroids. Br J Pharmacol. (2008) 154:502-21. doi: 10.1038/bjp.2008.165

17. De Souza GL, Hallak J. Anabolic steroids and male infertility: a comprehensive review. BJU Int. (2011) 108:1860-5. doi: 10.1111/j.1464-410X.2011. 10131.x

18. Gagliano-Jucá T, Pencina KM, Ganz T, Travison TG, Kantoff PW, Nguyen PL, et al. Mechanisms responsible for reduced erythropoiesis during androgen deprivation therapy in men with prostate cancer. Am J Physiol Endocrinol Metab. (2018) 315:E1185-93. doi: 10.1152/ajpendo.00272.2018

19. Larner J. Intermediary Metabolism and Its Regulation. EnglewoodCliffs, NJ: Prentice Hall Inc. (1971). p. 228.

20. Molinari PF, Chung SK, Snyder LM. Variations of erythrocyte glycolysis following androgens. J Lab Clin Med. (1973) 81:443-6.

21. Molinari PF, Neri LL. Effect of a single oral dose of oxymetholone on the metabolism of human erythrocytes. Exp Hematol. (1978) 6:648-54.

22. Bachman E, Feng R, Travison T, Li M, Olbina G, Ostland V, et al. Testosterone suppresses hepcidin in men: a potential mechanism for testosterone-induced erythrocytosis. J Clin Endocrinol Metab. (2010) 95:47437. doi: $10.1210 /$ jc.2010-0864
23. Naets JP, Wittek M. The mechanism of action of androgens on erythropoiesis. Ann N Y Acad Sci. (1968) 149:366-76.

24. Rishpon-Meyerstein N, Kilbridge T, Simone J, Fried W. The effect of testosterone on erythropoietin levels in anaemic patients. Blood. (1968) 31:453-60. doi: 10.1182/blood.V31.4.453.453

25. Hagenfeldt Y, Linde K, Sjoberg HE, Zumkeller W, Arver S. Testosterone increases serum 1,25-dihydroxyvitamin $\mathrm{D}$ and insulin like growth factor-I (IGF-1) in hypogonadal men. Int J Androl. (1992) 15:93-102. doi: 10.1111/j.1365-2605.1992.tb01118.x

26. Hobbs CJ, Plymate SR, Rosen CJ, Adler RA. Testosterone administration increases insulin-like growth factor-I levels in normal men. J Clin Endocrinol Metab. (1993) 77:776-9. doi: 10.1210/jc.77.3.776

27. Shahidi NT. Androgens and erythropoiesis. N Engl J Med. (1973) 289:72-80. doi: 10.1056/NEJM197307122890205

28. Krabbe S, Christensen T, Worm J, Christiansen C, Transbøl I. Relationship between haemoglobin and serum testosterone in normal children and adolescents and in boys with delayed puberty. Acta Paediatr Scand. (1978) 67:655-8. doi: 10.1111/j.1651-2227.1978.tb17818.x

29. Hero M, Wickman S, Hanhijärvi R, Siimes MA, Dunkel L. Pubertal upregulation of erythropoiesis in boys is determined primarily by androgen. $J$ Pediatr. (2005) 146:245-52. doi: 10.1016/j.jpeds.2004.09.002

30. Tong PC, Kong AP, So WY, Ng MH, Yang X, Ng MC, et al. Hematocrit, independent of chronic kidney disease, predicts adverse cardiovascular outcomes in Chinese patients with type 2 diabetes. Diabetes Care. (2006) 29:2439-44. doi: 10.2337/dc06-0887

31. Karakitsos D, Patrianakos AP, De Groot E, Boletis J, Karabinis A, Kyriazis J, et al. Androgen deficiency and endothelial dysfunction in men with end-stage kidney disease receiving maintenance hemodialysis. Am J Nephrol. (2006) 26:536-43. doi: 10.1159/000097816

32. Carrero JJ, Qureshi AR, Nakashima A, Arver S, Parini P, Lindholm B, et al. Prevalence and clinical implications of testosterone deficiency in men with end-stage renal disease. Nephrol Dial Transplant. (2011) 26:184-90. doi: $10.1093 /$ ndt/gfq397

33. Handelsman DJ. Hypothalamic-pituitary gonadal dysfunction in renal failure, dialysis, and renal transplantation. Endocr Rev. (1985) 6:151-82. doi: 10.1210/edrv-6-2-151

34. Handelsman DJ, Dong Q. Hypothalamo-pituitary gonadal axis in chronic renal failure. Endocrinol Metab North Am. (1993) 22:145-59. doi: 10.1016/S0889-8529(18)30184-1

35. Singh AB, Norris K, Modi N, Sinha-Hikim I, Shen R, Davidson T, et al. Pharmacokinetics of a transdermal testosterone system in men with end stage renal disease receiving maintenance hemodialysis and healthy hypogonadal men. J Clin Endocrinol Metab. (2001) 86:2437-45. doi: 10.1210/jc.86.6.2437

36. National Kidney Foundation. K/DOQI clinical practice guidelines for anemia of chronic kidney disease. Am J Kidney Dis. (2000) 37:182-238. doi: 10.1016/S0272-6386(01)70008-X

37. Kanagasundaram N, Shipley T, Wright R, Playford M, Peaston R, Moochhala $\mathrm{S}$, et al. The Prevalence of Androgen Deficiency in Male Patients With Advanced CKD - An Evaluation in Pre-dialysis and Haemodialysis Population. (2010). Available online at: http://www.renalarchive.org/FetchDoc.aspx?id= 6309 (accessed June 26, 2019).

38. Bello AK, Stenvinkel P, Lin M, Hemmelgarn B, Thadhani R, Klarenbach S, et al. Serum testosterone levels and clinical outcomes in male haemodialysis patients. Am J Kidney Dis. (2014) 63:268-75. doi: 10.1053/j.ajkd.2013. 06.010

39. Khurana KK, Navaneethan SD, Arrigain S, Schold JD, Nally JV, Shoskes DA. Serum testosterone levels and mortality in men with CKD stages 3-4. Am J Kidney Dis. (2014) 64:367-74. doi: 10.1053/j.ajkd.2014.03.010

40. DeLong M, Logan JL, Yong KC, Lien YH. Renin angiotensin blockade reduces serum free testosterone in middle-aged men on haemodialysis and correlates with erythropoietin resistance. Nephrol Dial Transplant. (2005) 20:585-90. doi: $10.1093 / \mathrm{ndt} / \mathrm{gfh} 638$

41. Pfeffer MA, Burdmann EA, Chen CY, Cooper ME, de Zeeuw D, Eckardt KU, et al. A trial of darbepoetin alfa in type 2 diabetes and chronic kidney disease. N Engl J Med. (2009) 361:2019-32. doi: 10.1056/NEJMoa0907845

42. Yang Q, Abudou M, Xie XS, Wu T. Androgens for the anaemia of chronic kidney disease in adults. Cochrane Database Syst Rev. (2014) 10:CD006881. doi: 10.1002/14651858.CD006881.pub2 
43. Adamu B, Ma'aji SM, Erwin PJ, Tleyjeh IM. Meta-analysis of randomized controlled trials on androgens versus erythropoietin for anaemia of chronic kidney disease: implications for developing countries. Int J Nephrol. (2012) 2012:580437. doi: 10.1155/2012/580437

44. Ballal SH, Domoto DT, Polack DC, Marciulonis P, Martin KJ. Androgens potentiate the effects of erythropoietin in the treatment of anaemia of end-stage renal disease. Am J Kidney Dis. (1991) 17:29-33. doi: 10.1016/S0272-6386(12)80246-0

45. Lawrence IG, Price DE, Howlett TA, Harris KP, Feehally J, Walls J. Correcting impotence in the male dialysis patient: experience with testosterone replacement and vacuum tumescence therapy. Am J Kidney Dis. (1998) 31:313-9. doi: 10.1053/ajkd.1998.v31.pm9469503

46. Johansen KL, Mulligan K, Schambelan M. Anabolic effects of nandrolone decanoate in patients receiving dialysis: a randomized controlled trial. JAMA. (1999) 281:1275-81. doi: 10.1001/jama.281.14.1275

47. Wu WC, Rathore SS, Wang Y, Radford MJ, Krumholz HM. Blood transfusion in elderly patients with acute myocardial infarction. N Engl J Med. (2001) 345:1230-6. doi: 10.1056/NEJMoa010615

48. Ezekowitz JA, McAlister FA, Armstrong PW. Anemia is common in heart failure and is associated with poor outcomes: insights from a cohort of 12,065 patients with new-onset heart failure. Circulation. (2003) 107:223-5. doi: 10.1161/01.CIR.0000052622.51963.FC

49. Guralnik JM, Eisenstaedt RS, Ferrucci L, Klein HG, Woodman RC. Prevalence of anemia in persons 65 years and older in the United States: evidence for a high rate of unexplained anemia. Blood. (2004) 104:2263-8. doi: 10.1182/blood-2004-05-1812

50. Tettamanti M, Lucca U, Gandini F, Recchia A, Mosconi P, Apolone G, et al. Prevalence, incidence and types of mild anemia in the elderly: the "Health and Anemia" population-based study. Haematologica. (2010) 95:1849-56. doi: 10.3324/haematol.2010.023101

51. Ferrucci L, Guralnik JM, Bandinelli S, Semba RD, Lauretani F, Corsi A., et al. Unexplained anaemia in older persons is characterised by low erythropoietin and low levels of pro-inflammatory markers. Br J Haematol. (2007) 136:84955. doi: 10.1111/j.1365-2141.2007.06502.x

52. Wu FC, Tajar A, Beynon JM, Pye SR, Silman AJ, Finn JD, et al. Identification of late-onset hypogonadism in middle-aged and elderly men. $N$ Engl J Med. (2010) 363:123-35. doi: 10.1056/NEJMoa0911101

53. Wu FC, Tajar A, Pye SR, Silman AJ, Finn JD, O’Neill TW, et al. Hypothalamicpituitary-testicular axis disruptions in older men are differentially linked to age and modifiable risk factors: the European Male Aging Study. J Clin Endocrinol Metab. (2008) 93:2737-45. doi: 10.1210/jc.2007-1972

54. Tajar A, Huhtaniemi IT, O'Neill TW, Finn JD, Pye SR, Lee DM, et al. Characteristics of androgen deficiency in late-onset hypogonadism: results from the European Male Aging Study (EMAS). J Clin Endocrinol Metab. (2012) 97:1508-16. doi: 10.1210/jc.2011-2513

55. Tajar A, Huhtaniemi IT, O’Neill TW, Finn JD, Pye SR, Lee DM, et al. Elevated luteinizing hormone despite normal testosterone levels in older men-natural history, risk factors and clinical features. Clin Endocrinol. (2018) 88:479-90. doi: $10.1111 /$ cen. 13524

56. Al-Sharefi A, Quinton R. Hiding in a plain sight: a high prevalence of androgen deficiency due to primary hypogonadism among acute medical inpatients with anaemia. Clin Endocrinol. (2018) 89:527-9. doi: $10.1111 /$ cen.13809

57. Dhindsa S, Ghanim H, Batra M, Kuhadiya ND, Abuaysheh S, Green $\mathrm{K}$, et al. Effect of testosterone on hepcidin, ferroportin, ferritin and iron binding capacity in patients with hypogonadotropic hypogonadism and type 2 diabetes. Clin Enocrinol. (2016) 85:772-28. doi: 10.1111/cen. 13130

58. Roy CN, Snyder PJ, Stephens-Shields AJ, Artz AS, Bhasin S, Cohen $\mathrm{HJ}$, et al. Association of testosterone levels with anemia in older men: a controlled clinical trial. JAMA Intern Med. (2017) 177:480-90. doi: 10.1001/jamainternmed.2016.9540

59. Al-Sharefi A, Quinton R. Re:male hypogonadism, a treatable yet forgotten cause of unexplained anaemia. REMARQ commentary on Strauder et al.Anemia at older age: etiologies, clinical implications, and management. Blood. (2018) 131:505-14. doi: 10.1182/blood-2017-07746446

60. Bhasin S, Brito JP, Cunningham GR, Hayes FJ, Hodis HN, Matsumoto AM, et al. Testosterone therapy in men with hypogonadism: an endocrine scoety clinical practice guidelines. J Clin Endocrinol Metab. (2018) 103:715-44. doi: $10.1210 /$ jc.2018-00229

61. UK Office for National Statistics. National Population Projections 2008Based. Newport: Office for National Statistics (2009) (accessed April 7, 2019).

62. Nishioka H, Koike S, Yamauchi M, Suga K, Esaki Y. Population projections by prefecture in Japan: 2005-2035 outline of results and methods. Jpn J Popul. (2011) 9:1-39. Available online at: http://www.ipss.go.jp/webj-ad/ WebJournal.files/population/2011_Vol.9/Web\%20Journal_Vol.9_01.pdf

Conflict of Interest: CJ received an honorarium for debating the safety of testosterone therapy at a meeting organized by Society of Endocrinology sponsored by Besins Healthcare.

The remaining authors declare that the research was conducted in the absence of any commercial or financial relationships that could be construed as a potential conflict of interest.

Copyright () 2019 Al-Sharefi, Mohammed, Abdalaziz and Jayasena. This is an openaccess article distributed under the terms of the Creative Commons Attribution License (CC BY). The use, distribution or reproduction in other forums is permitted, provided the original author(s) and the copyright owner(s) are credited and that the original publication in this journal is cited, in accordance with accepted academic practice. No use, distribution or reproduction is permitted which does not comply with these terms. 